\title{
Insecticidal Potential of some Fermented Native Plant Extracts for the Management of White Grub (Scarabaeidae: Coleoptera) Infestation on Potato Tubers in Skardu Baltistan
}

\author{
Muhammad Ayub ${ }^{1 *}$, Munir Hussain ${ }^{2}$, Sher Ahmad ${ }^{2}$, Syed Arif Hussain Rizvi ${ }^{3}$ Shahid Hussain ${ }^{1}$, \\ Muhammad Qasim ${ }^{2}$, Muhammad Din ${ }^{2}$, Muhammad Ishaque Mastoi ${ }^{4}$ and Tajudin ${ }^{2}$
}

${ }^{1}$ PARC, Agricultural Research Station, Skardu, Gilgit Baltistan, Pakistan; ${ }^{2}$ Mountain Agricultural Research Centre, Juglote, Gilgit, Pakistan; ${ }^{3}$ Institute of Plant and Environmental Protection, National Agriculture Research Centre, Islamabad, Pakistan; ${ }^{4}$ Plant Sciences Division, Pakistan Agricultural Research Council, Islamabad, Pakistan.

\begin{abstract}
Potato (Solanum tuberosum L.) is the fourth major food crop of the world and it is gaining status of cash crop in Gilgit Baltistan. White grub is most destructive insect pest damaging potato tubers and causes economic loss of Gilgit-Baltistan. The study was conducted with an aim to develop eco-friendly management of white grub. Fermented extracts of four herbs Sophora alopecuroides, Artemisia sieversiana, Peganum harmalla and Tagetes minuta were evaluated against white grub under field conditions for two consecutive growing seasons during 2018 and 2019. The minimum per cent infestation, number of white grubs per plot, yield loss and maximum tuber yield was recorded in plots treated with $S$. alopecuroides fermented extract and Refree. The fermented extract of $S$. alopecuroides significantly reduced percent infestation, number of white grub per plot and yield losses as compared to the control plot, however efficacy of the fermented extract of A. sieversiana, P. harmala and T. minuta was significantly low as compared to Refree. Our current field study indicated that the fermented extract of $S$. alopecuroides has potential to develop eco-friendly approach for management of white grub.

Received | May 26, 2020; Accepted | January 12, 2021; Published | March 23, 2021

*Correspondence | Muhammad Ayub, PARC, Agricultural Research Station, Skardu, Gilgit Baltistan, Pakistan; Email: ayubskd2011@gmail. com

Citation $\mid$ Ayub, M., M. Hussain, S. Ahmad, S.A.H. Rizvi, S. Hussain, M. Qasim, M. Din, M.I. Mastoi and Tajudin. 2021. Insecticidal potential of some fermented native plant extracts for the management of white grub (Scarabaeidae: Coleoptera) infestation on potato tubers in Skardu Baltistan. Pakistan Journal of Agricultural Research, 34(2): 259-265.

DOI | http://dx.doi.org/10.17582/journal.pjar/2021/34.2.259.265

Keywords | Plant extract, Insecticidal potential, Native plants, White grub, \% infestation, Yield loss
\end{abstract}

\section{Introduction}

$\mathrm{P}$ otato (Solanum tuberosum L.) is the fourth major food crop of the world. In Pakistan, currently potato is grown on 109.7 thousand hectares producing 1938.1 thousand tonnes annually with an average yield of 17.7 tons/ha. (Agricultural Statistics of Pakistan, 2003-2004).

Potato is now gaining status of cash crop after Apricot in Gilgit Baltistan (Food and Agriculture Division, 2012). Its annual production is estimated $76,125.00$ tonnes from an area of 3,045 hectares (Hashmi and Shafiullah, 2003). Potato crop is attacked by a number of insect pests including wireworms, white grub, aphids, cutworm and others adversely affecting the yield of crop (Shakur et al., 2007). Among these insect pests, white grub is the most destructive pest damaging potato tubers and causes significant economic loss to potato growers of Gilgit-Baltistan. 
White grubs are larvae of a Scarabid beetle in the order Coleoptera. There are about 1300 North American species and the world fauna of white grub exceeds 30,000 species (Mittal and Pajni, 2000). Several species of white grubs or scarabs are root feeding pests of grasses, grains, sugarcane, strawberry, potato tubers and young nursery plants (Crocker $e t$ al., 1996).

True white grubs are the larvae of May beetles (also called June Beetles) found in the genus Phyllophaga, of which there are over 100 different species. Phyllophaga larvae and other larvae of the family Scarabaeidae are often referred to as "white grubs", including larvae of the Japanese beetle (Popillia japonica Newman), annual white grubs (Cyclocephala spp.) and the green June beetle (Cotinis nitida Lin.) (Selmen, 1998).

White grubs are root feeders and their adult beetles feed on the leaves of host plants (Musthak et al.,2013). White grubs are the most destructive and troublesome soil insects, impeding potato production especially in hilly states of India. The infected tubers have scooped out holes or half-eaten tubers which are rendered unfit for marketing (Chandel et al., 2015).

Reliance on injudicious use of synthetic pesticides to control pests has also given rise to a number of problems such as destruction of non-target beneficial organisms (parasitoids and predators) affecting food chain and biological diversity, secondary outbreaks of pests that are normally under natural control resulting in their rapid proliferation (Ouedraogo et al., 2011). There have also been cases of pests becoming tolerant to insecticides resulting in the use of double and triple rate of application (Stoll, 2000).

Although synthetic insecticides are used as the main controlling agent, optimal control cannot be obtained probably due to the development of insecticide resistance. Also, the uses of synthetic insecticides pollute the environment and can seriously affect the health of the farming communities. Therefore, search for natural product-based insecticides (botanicals), which are biodegradable and economically has become an area of extensive research. Resistance to botanicals does not develop as rapidly as to synthetic insecticides due to the structural complexity of natural toxicants (Silva et al., 2008). About 250,000 plant species in the world have been reported to possess compounds with insecticidal properties (Rafael, 2001).
The chemical insecticides are not effective in the white grub management system and these chemical pesticides are hazardous for human health and other organisms. Green plants are reservoir of effective and valuable natural source of pesticide (Hostettmann et al., 1997).

Interest in the use of bio-pesticides with selectivity towards phytophagous insects has increased in recent years, particularly in cropping systems that rely on natural enemies as a major component of integrated pest management (Rausell et al., 2000). In GilgitBaltisan (G-B) farmers are using toxic chemical insecticides injudiciously to control white grub.

Floral diversity in Gilgit-Baltistan is rich with wide spectrum of medicinal values but no effort has been made in this region to isolate, identify, and develop botanical pesticides. Rich biodiversity in G-B has potential opportunities to develop botanical pesticides formulation unit as in most parts of the GilgitBaltistan plant materials are also used traditionally to control insect pests (Ismail et al., 2014). Sophora alopecuroides found in Skardu (Baltistan) abundantly has the potential to commercialize as a natural pesticide against various insect pests (Rizvi et al., 2019).

In the area where this study has been conducted, farmers rely on toxic chemicalinsecticides injudiciously to control white grub. The massive use of synthetic insecticides in pest management program exerts hazardous effects on human health and environment. There is a dire need to adopt eco-friendly approach for pest management, therefore in this study fermented extracts of four readily available local plants were evaluated for their insecticidal potential against white grub infestation on potato crop.

\section{Materials and Methods}

\section{Preparation of fermented plant extract}

The aerial parts of native plants Sophora alopecuroides (called Khampa in local language "Balti"), Artemisia sieversiana (Khahuro), Peganum harmala (Isman) and Tagetes minuta (Suna Mindoq) were harvested at preblooming stage. The plant materials were washed thoroughly and then dried in shade. The dried plant materials were grinded to form fine powder and stored in hermetically sealed jars. Fermented extracts of four plants were prepared by dipping their powder 
in stream water in $25 \mathrm{~kg}$ capacity drums at 1: $9 \mathrm{w} / \mathrm{v}$. Openings of drums were wrapped with muslin cloths and then placed in semi-shade for fermentation. Plant materials in drums were stirred daily. After two weeks fermented extracts were filtered through muslin cloth and then filter paper (Whatman No.1). These extracts were stored in glass jars placed in a cool dark place until field application.

\section{Field application}

Field experiments to evaluate the insecticidal effects of fermented extracts derived from four native plants against white grub were carried out at PARC, Agricultural Research Station, Skardu during two successive seasons of 2018 and 2019 under Randomized Complete Block Design with 13 treatments and 3 replications. Potato variety "Flamenco" was planted maintaining a plot size of $6.67 \mathrm{~m}^{2}$ for each treatment with two $45 \mathrm{~cm}$ wide ridges of 5 meters length. Serial concentrations of fermented extracts were prepared by diluting @ 1, 3 and $5 \mathrm{ml} /$ liter of water and drenching of this diluted extract was carried out @1000 1/ha on top of potato ridges in the evening hours whereas control plots were left untreated. Refree granules (Active IngredientFipronil 0.3\% G.) were applied during 2019 as standard control. Drenching was carried out twice in a season at one-month interval. First application of extracts was given on tuber formation initiated after one month of planting in mid-June. Total number of tubers and damaged tubers were recorded to determine \% infestation. Number of white grubs found in each plot and weight of tubers per plot were recorded at harvesting time for assessment of yield and $\%$ yield loss.

\section{Statistical analysis}

All the statistical tests were conducted by using SPSS 17.0; $P$-values of less than 0.05 were considered significant. For the percent infestation, damage and yield data under field conditions were subjected to repeated measured analyses were subjected to simple analyses of variance. PROC GLIMMIX (SAS Institute, 2010) was used. All statistical analyses were conducted at the 0.05 level of significance.

\section{Results and Discussion}

\section{Results obtained during 2018}

Statistical analysis indicated highly significant difference in $\%$ tuber infestation between plots treated with $S$. alopecuroides fermented extracts at doses 3 and $5 \mathrm{ml} / 1$ and other plots. In plots treated with 1 , 3 and $5 \mathrm{ml} / 1$ doses of $T$. minuta, $A$. sieversiana 1,3 $\mathrm{ml} / 1$ P. harmala and $1 \mathrm{ml} / \mathrm{L}$ S. alopecuroides fermented extracts moderate tuber infestations of 10.84 to 21.60 $\%$ were recorded. Results of this study revealed that drenching of $S$. alopecuroides fermented extract twice significantly reduced the white grub infestation on potato tubers to $1.67 \%$ and $4.05 \%$ at concentrations of 5 and $3 \mathrm{ml} / 1$ compared to untreated control plots and $P$. harmala extract $5 \mathrm{ml} / 1$ dose treated plots with significantly highest infestation of $24.06 \%$ (Table 1 , Figure 1).

In case of number of white grub counted per plot at time of harvesting, there was significant difference among treatments $(P=0.005)$ but there was no difference between treatments of $S$. alopecuroides extract doses of 3 and 5 ml/1@10001/ha. As shown in Table 1 from plots treated with $S$. alopecuroides extract $3 \mathrm{~mL} / \mathrm{L}$ and $5 \mathrm{~mL} / \mathrm{L}$ lowest number of white grub 0.33 and 0.00 were captured, which significantly differed from other treatments during 2018. Without statistical difference, higher number of white grubs $7.67,7.00$ and 5.67 were recorded from control and plots treated with $P$. barmala extract at doses of 1 and $3 \mathrm{ml} / 1$.

Similarly, there was significant difference in tuber yield obtained from plots treated with four fermented plant extracts and untreated control plots. Two applications of $S$. alopecuroides fermented extract at $5 \mathrm{ml} / 1$ significantly increased the tuber yield to maximum $27.64 \mathrm{t} / \mathrm{ha}$ followed by $19.74 \mathrm{t} / \mathrm{ha}$ tuber yield recorded from plots treated with $3 \mathrm{ml} / 1$ of same extract. Among other treatments including control, no significant difference was observed in tuber yield which ranged from $11.74 \mathrm{t} / \mathrm{ha}$ to $15.49 \mathrm{t} / \mathrm{ha}$.

Results of this study revealed that infestation of white grubs on potato tuber caused significant loss of potato yield i.e., up to $58.40 \%$ but drenching of $S$. alopecuroides fermented extracts at 3 and $5 \mathrm{ml} / 1$ significantly reduced tuber yield loss to $28.58 \%$ and $5.31 \%$

\section{Results obtained during 2019}

Minimum infestation (3.47\%) was recorded in standard control plots treated with Refree (Active Ingredient Fipronil 0.3\% G) which did not differ significantly from $5.75,3.85 \%$ infestation observed in plots treated with 3 and $5 \mathrm{ml} / 1$ of $S$. alopecuroides 
fermented extracts as shown in Table 2. Results indicate that the effect of synthetic pesticide used in the study has no significant difference with fermented extract of $S$. alopecuroides and $A$. sieversiana on reduction in white grub infestation. Statistically, \%infestation in plots treated with fermented extracts of T. minuta, $A$. sieversiania and $P$. harmala did not vary significantly with each other but significantly differed from plots treated with $S$. alopecuroides fermented extracts (3 and $5 \mathrm{ml} / \mathrm{l})$, A. sieversiana $(5 \mathrm{ml} / \mathrm{l})$, Refree $(45 \mathrm{~kg} / \mathrm{ha})$ and control plots with significant difference receiving maximum infestation of $34.82 \%$.

With no significant difference, lowest number of white grub 0.00, 0.33 and 0.67 were recorded in plots treated with 1 and $5 \mathrm{ml} / 1 \mathrm{~S}$. alopecuroides extract and Refree. Highest number of white grub 7.67, 8.67 and 8.33 were found in plots treated with extract dose of T. minuta $3 \mathrm{ml} / 1$, and $P$. harmala extract doses 1 and 3 $\mathrm{ml} / 1$ respectively with no statistical difference. Higher number of white grubs i.e., 5.00 were recorded in untreated control plots which did not significantly differ from plots treated with fermented extracts of $T$. minuta, $A$. sieversiana, . harmala at 1,3 and $5 \mathrm{ml} / 1$ and $S$. alopecuroides $3 \mathrm{ml} / 1$ but significantly differed from plots treated with Refree $45 \mathrm{~kg} / \mathrm{h}$ a and $S$. alopecuroides extract at $1 \mathrm{ml} / 1$ and $5 \mathrm{ml} / 1$ concentrations.

Table 1: Effect of Fermented extracts of four native plants on white grub infestation on potato under field condition during 2018.

$\begin{array}{llllll}\text { Fermented extract } & \text { Dose } \mathbf{~ m L / L} & \text { \% infestation } & \text { No. of white rub/6.67 } \mathbf{m}^{\mathbf{2}} & \text { Yield t/ha } & \text { \% yield loss } \\ \text { S. alopecuroides } & 1 & 10.84 \mathrm{cde} & 3.00 \mathrm{ab} & 15.49 \mathrm{~b} & 43.96 \mathrm{a} \\ & 3 & 4.047 \mathrm{de} & 0.33 \mathrm{~b} & 19.74 \mathrm{ab} & 28.58 \mathrm{ab} \\ & 5 & 1.667 \mathrm{e} & 0.00 \mathrm{~b} & 27.64 \mathrm{a} & 5.31 \mathrm{~b} \\ \text { T. minuta } & 1 & 20.07 \mathrm{abc} & 3.67 \mathrm{ab} & 11.74 \mathrm{~b} & 57.51 \mathrm{a} \\ & 3 & 12.35 \mathrm{bcd} & 4.00 \mathrm{ab} & 14.24 \mathrm{~b} & 48.48 \mathrm{a} \\ & 5 & 20.22 \mathrm{abc} & 4.33 \mathrm{ab} & 13.62 \mathrm{~b} & 51.93 \mathrm{a} \\ \text { A. sieversiana } & 1 & 20.75 \mathrm{abc} & 4.00 \mathrm{ab} & 12.75 \mathrm{~b} & 53.88 \mathrm{a} \\ & 3 & 16.70 \mathrm{abc} & 3.67 \mathrm{ab} & 14.50 \mathrm{~b} & 58.40 \mathrm{a} \\ & 5 & 14.97 \mathrm{abc} & 3.00 \mathrm{ab} & 14.74 \mathrm{~b} & 46.67 \mathrm{a} \\ \text { P. harmalla } & 1 & 21.60 \mathrm{ab} & 7.00 \mathrm{a} & 12.39 \mathrm{~b} & 55.17 \mathrm{a} \\ & 3 & 18.24 \mathrm{abc} & 5.67 \mathrm{a} & 14.49 \mathrm{~b} & 47.57 \mathrm{a} \\ & 5 & 24.06 \mathrm{a} & 3.67 \mathrm{ab} & 13.99 \mathrm{~b} & 49.37 \mathrm{a} \\ \text { Control } & - & 24.95 \mathrm{a} & 7.67 \mathrm{a} & 13.24 \mathrm{~b} & 52.88 \mathrm{a}\end{array}$

Data are the mean of three replicates and are represented as mean \pm standard deviation. Means in the same column followed by the same lower-case letter are not significantly different at $P=0.05$.

Table 2: Effects of Fermented extracts of four native plants on white grub infestation on potato tubers under field condition, 2019.

\section{Fermented extract}

S. alopecuroides

S. alopecuroides

T. minuta

A. sieversiana

5

P. harmalla

Refree

Control

\section{Dose mL/L} 1 3

5

1 3 5

\section{1}

3

5

1

3

5

$45 \mathrm{~kg} / \mathrm{ha}$

\% infesta
$15.00 \mathrm{cde}$
$5.75 \mathrm{e}$
$3.85 \mathrm{e}$
$25.58 \mathrm{abc}$
$24.62 \mathrm{abc}$
$27.58 \mathrm{abc}$
$26.38 \mathrm{abc}$
$17.49 \mathrm{bcd}$
$10.52 \mathrm{de}$
$31.35 \mathrm{ab}$
$32.09 \mathrm{ab}$
$29.64 \mathrm{ab}$

$3.47 \mathrm{e}$

$34.82 \mathrm{a}$
No. of white grub captured/plot

$0.33 \mathrm{e}$
$1.00 \mathrm{de}$
$0.67 \mathrm{e}$

$5.33 \mathrm{abc}$

$7.67 \mathrm{a}$

3.33bcde

$3.00 \mathrm{bcde}$

2.33bcde

$1.67 \mathrm{cde}$

$8.67 \mathrm{a}$

$8.33 \mathrm{a}$

$6.33 \mathrm{ab}$

$0.00 \mathrm{e}$

$5.00 \mathrm{abcd}$

$\begin{array}{ll}\text { Yield t/ha } & \text { \% yield loss } \\ 12.49 \mathrm{c} & 50.51 \mathrm{a} \\ 18.49 \mathrm{abc} & 26.74 \mathrm{abc} \\ 23.99 \mathrm{ab} & 8.25 \mathrm{bc} \\ 13.99 \mathrm{c} & 44.56 \mathrm{a} \\ 12.99 \mathrm{c} & 48.52 \mathrm{a} \\ 11.10 \mathrm{c} & 54.45 \mathrm{a} \\ 11.64 \mathrm{c} & 53.90 \mathrm{a} \\ 14.49 \mathrm{bc} & 42.58 \mathrm{ab} \\ 16.24 \mathrm{abc} & 35.64 \mathrm{abc} \\ 12.99 \mathrm{c} & 48.52 \mathrm{a} \\ 12.24 \mathrm{c} & 51.49 \mathrm{a} \\ 12.10 \mathrm{c} & 48.51 \mathrm{a} \\ 25.24 \mathrm{a} & 4.62 \mathrm{c} \\ 11.10 \mathrm{c} & 56.03 \mathrm{a}\end{array}$

Data are the mean of three replicates and are represented as mean \pm standard deviation. Means in the same column followed by the same 
lower-case letter are not significantly different at $P=0.05$.

In case of potato tuber yield, maximum tuber yield of $25.24 \mathrm{t} / \mathrm{ha}$ was obtained from plots treated with Refree which did not differ significantly from $18.49 \mathrm{t} / \mathrm{ha}, 23.99 \mathrm{t} / \mathrm{ha}$ and $16.24 \mathrm{t} / \mathrm{ha}$ tuber yield, respectively recorded from plots treated with $S$. alopecuroides extracts at 3 and $5 \mathrm{ml} / 1$ and $A$. sieversiana extract at $5 \mathrm{ml} / 1$ doses. Minimum tuber yield of 11.10 t/ha obtained from the control and T. minuta $5 \mathrm{ml} / 1$ treated plots was not significantly different from tuber yields of 11.64 and 18.49 t/ha obtained from plots treated with $S$. alopecuroides extract doses 1 and $3 \mathrm{ml} / 1$ and T. minuta, $A$. sieversiana, $P$. harmala extracts at 1 $\mathrm{ml} / 1,3 \mathrm{~m} / 1$ and $5 \mathrm{ml} / 1$ dose levels. Potato tuber yield of $16.24 \mathrm{ha} / \mathrm{t}$ obtained from $A$. sieversiana $5 \mathrm{ml} / \mathrm{L}$ extract treated plot was not significantly different from maximum tuber yield of 25.24 t/ha from plot treated with Refree, while minimum yield of $11.10 \mathrm{t} /$ ha was obtained from the control plot and $23.99 \mathrm{t} / \mathrm{ha}$ yield was obtained from $S$. alopecuroides $5 \mathrm{ml} / 1$ treated plot as shown (Table 2, Figure 2).

Assessment of potato yield loss indicated that white grub caused severe damage to tubers resulting in yield loss of up to $56.03 \%$. Highest yield loss of $56.03 \%$ recorded control plots was not significantly different from $26.74 \%$ to $54.45 \%$ yield loss recorded in plots treated with 1 and $3 \mathrm{ml} / 1$ of $S$. alopecuroides extract and plots treated with 1,3 and $5 \mathrm{ml} / 1$ of $T$. minuta, $A$. sieversiana, $P$. harmala extracts but significantly differed from lowest yield loss of $4.62 \%$ in plots treated with Refree, $26.74 \%$ and $8.25 \%$ from $S$. alopecuroides 3 and $5 \mathrm{ml} / 1$ and $35.64 \%$ yield loss from A. sieversiana $5 \mathrm{ml} / 1$ treated plot. However, yield loss of $26.74 \%$ and $35.64 \%$ recorded in plots treated with $3 \mathrm{ml} / 1 \mathrm{~S}$. alopecuroides and $5 \mathrm{ml} / 1$ A. sieversiana was not significantly different from highest yield loss of $56.03 \%$ from control and other plots. Results indicated that two applications of Refree at rate of $45 \mathrm{~kg} / \mathrm{ha}$ and $S$. alopecuroides $5 \mathrm{ml} / 1$ at rate of $100 \mathrm{l} /$ ha significantly reduced the potato tuber yield loss to $4.62 \%$ and $8.27 \%$ from an economical yield loss of $56.03 \%$ caused by white grub attack during 2019 .

White grub is an important agricultural root feeding pest widely distributed in different agro-climatic conditions of Pakistan and throughout the world. White grubs attack potato which is one of the four major staple foods having a significant contribution to national food consumption needs.
Results of present study revealed that $S$. alopecuroides fermented extract is most effective to manage white grub infestation reducing tuber damage under field conditions.

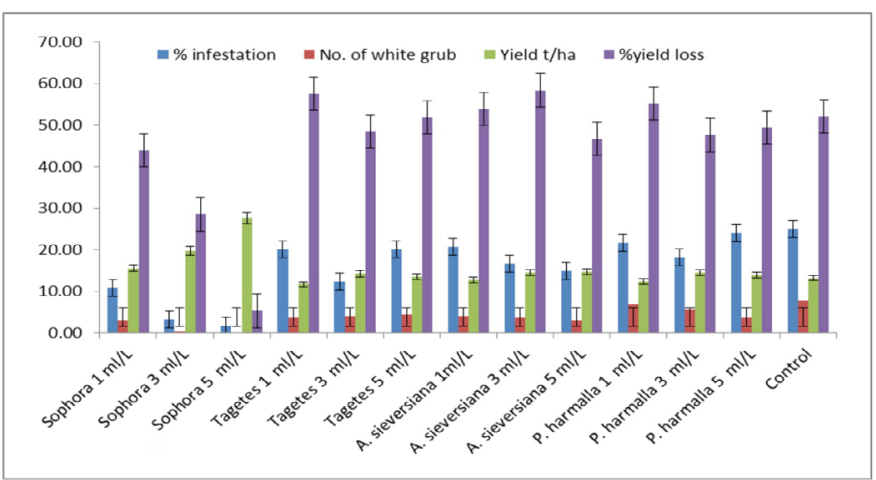

Figure 1: Effect of Fermented extracts of four native plants on white grub infestation on potato under field condition during 2018.

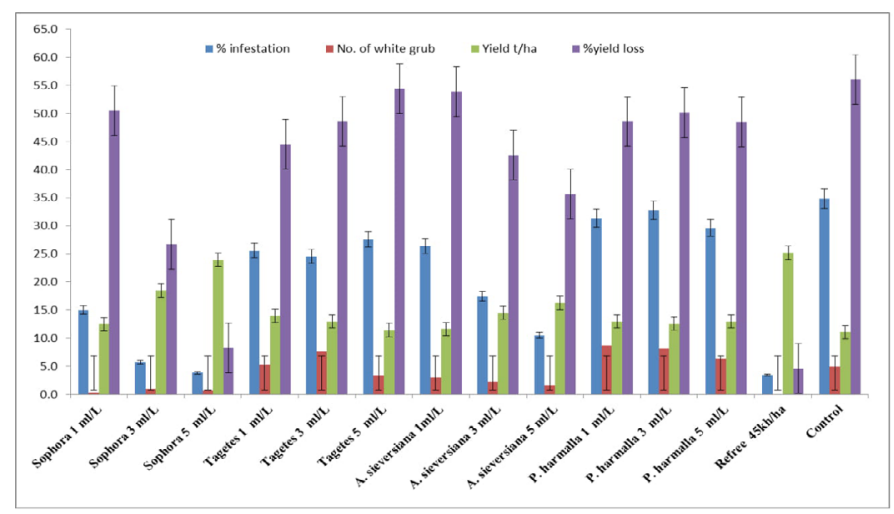

Figure 2: Effect of Fermented extracts of four native plants on white grub infestation on potato under feld condition, 2019.

In concurrence with the results of present study, Yadava and Sharma (1995) reported that white grubs cause up to $70 \%$ damage to roots of commercial crops and one grub/ $\mathrm{m}^{2}$ caused $80-100$ per cent plant mortality. Similar damage rate in potato tubers varying from 8.5 to $75.05 \%$ especially in hilly regions of India reported by Chandel et al. (2015). Rani et al. (2009) found fermented extracts of Sapindus mukorossi, Chrysanthemum sp., Nerium oleander, Urtica diocia and Vitex negundo in indigenous cow urine @ $5 \mathrm{~mL} / \mathrm{L}$ were equally effective and the per cent tuber damage on tuber number basis in these treatments varied from1.67-9.58\% during 2007 and 5.08-7.46\% during 2008 crop season. Similarly, the result of studies on effectiveness of fermented cattle urine (1:6) and natural products of Nicotiana tabacum, Azadirachta indica, Capsicum annum and Allium cepa in the management of barley aphid, Diuraphis noxia carried out in Ethiopia revealed that all the treatments were toxic to $D$. noxia and provided more 
than double increase in yield (Tesfaye and Gautam, 2003). Furthermore, Sahayaraj et al. (2011) reported more than $90 \%$ larval mortality in Spodoptera litura released onto castor leaves treated with 13,18 and 23 days old fermented extracts of Calotropis gigantea and Pongamia pinnata leaves. In another similar study, Baloc and Bulong (2015) reported that fermented extracts of Azadirachta indica, Gliricidia sepium, Tagetes erecta and Tinospora rumphii were equally effective as the synthetic pesticides in terms of final plant height, average number of white flies reduced after spraying and average number of 28 -spotted beetles reduced after spraying.

\section{Conclusions and Recommendations}

Results of this study revealed that white grubs cause considerable infestation and potato tuber yield loss. Fermented extract of $S$. alopecuroides a readily available plant has the potential insecticidal activity against white grub infestation on potato crop and can be used as a novel alternative to synthetic insecticides for ecofriendly management of white grub, a polyphagus soil insect pest damaging all sorts of field crops, forest trees and ornamental plants. Further studies should be focused on different fermentation techniques, formulations, phytotoxicity and application methods.

\section{Acknowledgements}

This investigation was carried out under financial assistance of Agricultural Linkages Program (ALP), PARC which is gratefully acknowledged. Authors are also thankful to Regional Coordinator, Economic Transformation Initiatives (ETI), Skardu for providing potato seed (var. Flamenco) to carry out the experiments.

\section{Novelty Statement}

Every years tons of chemical insecticides are being used to control white grub in spite of serious health and environmental risks. Our current study emphasizes the insecticidal potential of native plants for eco-friendly cheaper management of white grub infestation on potato and other field crops to reduce the use of harmful synthetic insecticides

\section{Author's Contribution}

Muhammad Ayub, Syed Arif Hussain Rizvi and June 2021 | Volume 34 | Issue 2 | Page 264
Shahid Hussain contributed to overall management of the research work, data analysis and writing of the article. Munir Hussain, Sher Ahmad, Muhammad Qasim, Muhammad Din, Muhammad Ishaque Mastoi and Tajudin gave technical inputs and proofread the paper.

\section{Conflict of interest}

The authors have declared no conflict of interest.

\section{References}

Agricultural Statistics of Pakistan, www.faostat. fao.org

Baloc H.A., P. Marissa and M.P. Bulong. 2015. Efficacy of fermented botanical plant extracts in the management of white flies and 28-Spotted beetles in tomato. Int. J. Sci. Res., 4(7): 25662569.

Chandel, R.S., M. Pathania, K.S. Verma, B. Bhatacharyya, S. Vashisth and V. Kumar. 2015. The ecology and control of potato white grubs of India. Potato Res., 58(2): 147-164. https:// doi.org/10.1007/s11540-015-9295-3

Crocker, R.L., L.A. Rodriguez-del-Bosque, W.T. Nailon and X. Wei. 1996. Flight periods in Texas of three parasites (Diptera: Pyrgotidae) of adult Phyllophaga spp. (Coleoptera: Scarabaeidae) and egg production by Pyrgota undata. Southwestern Entomol., 21: 317-324.

Food and Agriculture Division, 2012. Agriculture statistics of Pakistan. Ministry of Food and Agric. and Cooperat. Econ. Wing, Govt. of Pakistan, Islamabad, pp. 230-290.

Hashmi, A.A. and Shafiullah. 2003. NASSD Background Paper: Agriculture and Food Security. IUCN Pakistan, Northern Areas Progamme, Gilgit.

Hostettmann,K.J.andW fender.1997.The search for biological active secondary metabolites.J.Pestic. Sci., 51: 471-482. https://doi.org/10.1002/ (SICI)1096-9063(199712)51:4<471::AIDPS662>3.0.CO;2-S

Ismail, M., F. Hussain and S. Ali. 2014. Botanical biopesticide and insect repellent from Tanacetum baltistanicum Endemic to Gilgit-Baltistan. J. Biodiv. Environ. Sci., 58(2): 128-135.

Mittal, I.C. and H.R. Pajni. 2000. New species belonging to (Coleoptera: scarabaeid: Melolonthidae) from India. J. Ent., 2: 85-88. 
Musthak, A.T.M., G. Sharma, Y.S. Mathur and R.B.L. Gupta. 2013. Biosystematics of phytophagous Scarabaeidae- an Indian overview. In: (Eds.). Ind. Phytol., 2(5): 83-85.

Ouedraogo, M., A.M. Toe, T.Z. Ouedraogo and P.I. Guissou. 2011. Pesticides in burkina faso: Overview of the situation in a Sahalian African country. Pesticide in the Modern World: Pesticides uses and Management. Juneza Trdin 9, 51000 Rijeka, Croata. https://doi. org/10.5772/16507

Rafael, E., 2001. Botanical insecticides. www. ipmworld. umn.edu/silvia.html. Accessed on 12 October 2019.

Rani, P., Y. Thakur, A. Sharma, A. Sharma and V.K. Chandla. 2009. Biointensive Management of White Grubs with Botanical Extracts in Indigenous Cow (Hariana) Urine. Potato J., 36(1-2): 61-64.

Rausell, C.A., C. Martineze-Ramirez, GraciaRobiess and M.D. Real.2000. A binding site for Bacillus thuringiensis Cry $1 \mathrm{Ab}$ toxins lost during larval development in two forest pests. Appl. Environ. Microbiol., 66: 1553-1583. https:// doi.org/10.1128/AEM.66.4.1553-1558.2000

Rizvi, S.A.H., S. Ling, F.F. Tian, J. Liu and X. Zeng. 2019. Interference mechanism of Sophora alopecuroides L. alkaloids extract on host finding and selection of the Asian citrus psyllid Diaphorina citri Kuwayama (Hemiptera: Psyllidae). Environ. Sci. Pollut. Res., 26(2): 1548-1557. https://doi.org/10.1007/s11356018-3733-0

SAS Institute, Inc. 2010. SAS Note 40724, "Comparing covariance structures, testing covariance parameters using the COVTEST statement in PROC GLIMMIX.”. Cary, NC: SAS Institute Inc. Available at support.sas. $\mathrm{com} / \mathrm{kb} / 40 / 724 . h t m l$.

Sahayaraj, K., P. Kombiah and D.S. Kumar. 2011. Evaluation of Insecticidal Activity of Fermented Plant Products on Spodoptera litura (Fab.). Indian J. Agric. Res., 45(1): 77- 82. www. arccjournals.com / indianjournals.com

Selmen, L., 1998. White Grubs-Polyphaga and other Species, Department of Entomology and Nematomology, University of Florida.

Shakur, M., F. Ullah, M. Naem, M. Amin, A.U.R. Saljoqi and M. Zamin. 2007. Effect of various insecticides for the control of potato cutworm (Agrotis ipsilon Huf, Noctuidae: Lepidoptera) at Kalam Swat. Sarhad J. Agric., 23(2): 423-426.

Silva, W.A.P.P.de, G.K. Manuweera and S.H.P.P. Karunaratne. 2008. Insecticidal activity of Euphorbia antiquorum L. latex and its preliminary chemical analysis. J. Natl. Sci. Found. Sri Lanka, 36(1): 15-23. https://doi. org/10.4038/jnsfsr.v36i1.129

Stoll, G., 2000. Natural plant protection in the tropics: Letting information come to life. $2^{\text {nd }}$ edn. Magraf Verlag, Weikersheim. pp. 376.

Tesfaye, A. and R.D. Gautam. 2003. Traditional pest management practices and lesser exploited natural product in Ethiopia and India, appraisal and revalidation. Indian J. Trad. Knowl., 2: 189201.

Yadava, C.P.S. and G.K. Sharma. 1995. Indian white grubs and their management. Technical Bulletin No. 2. Project Co-ordinating Centre, AlCRP on white grubs, Durgapura, Jaipur, pp. 26. 